\title{
Pyogenic Granuloma of Giniva
}

\section{Introduction}

Pyogenic granuloma is a commonly occurring inflammatory hyperplasia of the skin and oral mucosa. It is not associated with pus as its name suggests and histologically it resembles an angiomatous lesion rather than a granulomatous lesion [1]. It is known by a variety of names such as Crocker and Hartzell's disease, granuloma pyogenicum, granuloma pediculatum benignum, benign vascular tumor and during pregnancy as granuloma gravidarum [2]. A 27 year old lady presented to a private dental clinic with the chief complaint of painful swelling on her front left region of oral cavity from 1 month. Past medical history and family history of the patient was non - relevant to the presenting symptom.

Intra - oral examination revealed a red to purple nodule associated with the gingiva of teeth \#33, \#34 and \#35 measuring about $2 \times 2 \mathrm{~cm}$. The color of the swelling was red to purple, on palpation it was found to be soft to firm. There were no sign of abscess and discharge. (Figure 1) Intra - oral periapical radiograph revealed no association of the swelling with alveolar bone. Excisional biopsy was taken and soft tissue sample was sent to the Department of Oral and Maxillofacial Pathology NIMS Dental college for histopathological evaluation.

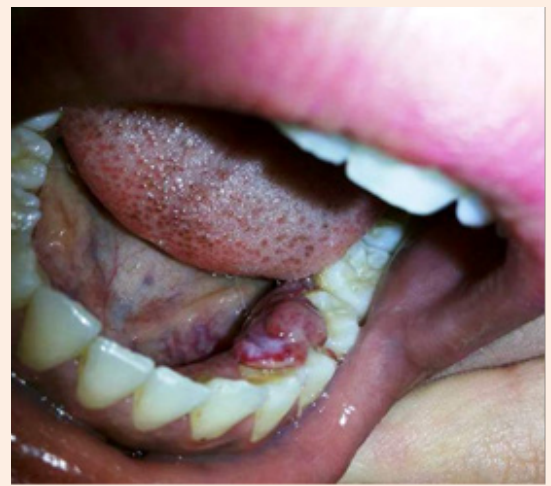

Figure 1: Clinical picture of the lesion.

Histopathological examination of hematoxylin and eosin stained soft tissue section revealed. A connective tissue stroma densly infiltrated with chronic inflammatory cells chiefly composed of lymphocytes. (Figure 2) Numerous dilated blood vessels lined by endothelial cells and having erythrocytes inside were seen. (Figure 3) The overlying epithelium was ulcerated (Figure 4).

Based on all the features a final diagnosis of pyogenic granuloma rendered. In 1844, Hullihen described the first case of pyogenic granuloma in English literature [1]. In 1897, pyogenic granuloma in man was described as "botryomycosis hominis. in 1904 is credited with giving the current term of "pyogenic granuloma" or "granuloma pyogenicum [2].

Clinical Images
Volume 1 Issue 1 - 2016
Manas Bajpai* and Nilesh Pardhe
Department of Oral and Maxillofacial Pathology, NIMS Dental
College, India
*Corresponding author: Manas Bajpai, Department of
Oral and Maxillofacial Pathology, NIMS Dental College
Jaipur (Rajasthan), India, Tel: 918890599751; Email:
dr.manasbajpai@gmail.com
Received: November 11, 2016 | Published: December 30,
2016

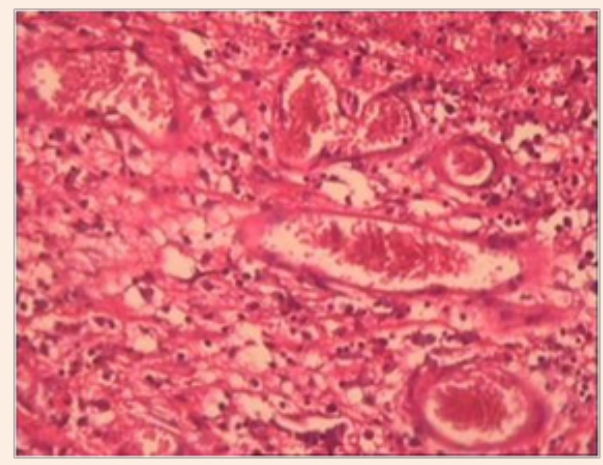

Figure 2: Infiltration of lymphocytes and dilated blood vessels lined by endothelial cells. (Hematoxylin and Eosin stain X20).

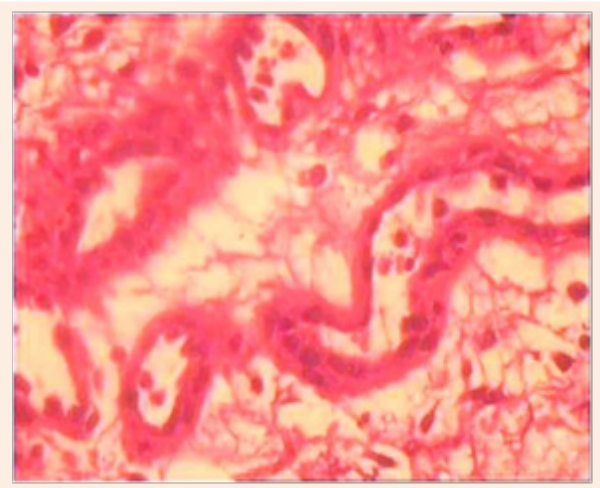

Figure 3: Dilated blood vessels lined by endothelial cells (Hematoxylin and Eosin stain X 40).

Differential diagnosis included peripheral giant cell granuloma, peripheral ossifying fibroma, metastatic cancer, hemangioma, pregnancy tumor, conventional granulation tissue hyperplasia, Kaposi's sarcoma, bacillary angiomatosis and non-Hodgkins lymphoma [3]. 


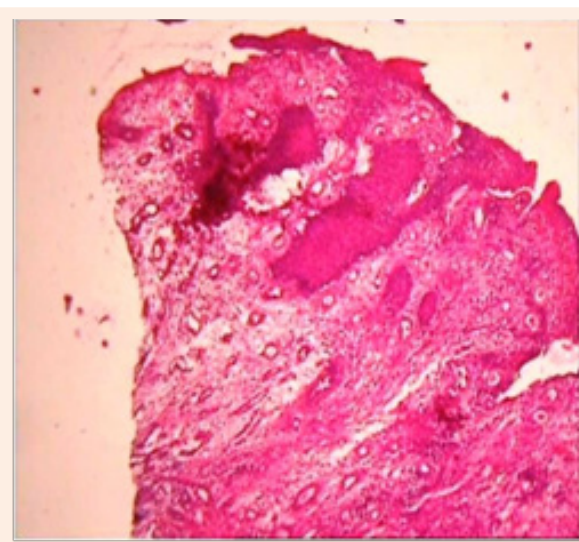

Figure 4: Ulcerated overlying epithelium with highly vascular connective tissue stroma.

\section{References}

1. Hullihen SP (1844) Case of aneurism by anastomosis of the superior maxillae. Am J Dent Sci 4: 160-162.

2. Bhaskar SN, Jacoway JR (1966) Pyogenic granuloma - Clinical features, incidence, histology, and result of treatment: Report of 242 cases. J Oral Surg 24(5): 391-398.

3. Bajpai M, Kumar M, Kumar M, Agarwal D (2014) Pigmented Lesion of Buccal Mucosa. Case Reports in Medicine p. 3. 